Authors have nothing to disclose with regard to commercial support.

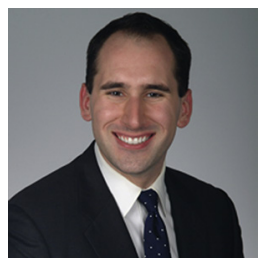

\section{MITRAL ANNULOPLASTY RING DEHISCENCE: OPTIMAL FORCE DISTRIBUTION WITH FLEXIBLE RINGS}

\section{To the Editor:}

We read with great interest the case report by Pierce and colleagues ${ }^{1}$ describing the measurement of suture tension during mitral annuloplasty ring dehiscence in a beating-heart ovine model. In an induced hypercontractile state, they noted a high peak suture tension in the midtrigonal region that abruptly decreased with suture dehiscence. A significant increase in tension was then transferred instantaneously to the adjacent 2 sutures. The notion that ring dehiscence begins with a single point of increased tension that is sequentially distributed along the ring is intuitively appealing. Although this particular observation may have been to the result of misplacement of the culprit suture, the ability to measure the tension at each of the annuloplasty sutures provided an elegant demonstration of this phenomenon.

We (J.R.S., J.A.S.) previously performed an in vitro experimental study comparing the force required for ring dehiscence using combinations of annuloplasty rings (rigid and flexible) and suture techniques (interrupted mattress and a running suture technique). ${ }^{2}$ We demonstrated that a far greater force was required to disrupt flexible rings secured with a single running suture than either type of ring secured with mattress sutures. The mode of failure in the flexible ring-running suture group most often was tissue disruption remote from the annulus rather than ring separation, which was the failure mode when mattress sutures were used.

A deep understanding of mitral valve anatomy and physiologic function, in both normal and pathological states, is now possible as a result of many recent elegant studies. For example, it is well established that the mitral annulus is a highly dynamic, saddle-shaped structure that changes configuration throughout the cardiac cycle. ${ }^{3}$ It

\footnotetext{
The Editor welcomes submissions for possible publication in the Letters to the Editor section that consist of commentary on an article published in the Journal or other relevant issues. Authors should: • Include no more than 500 words of text, three authors, and five references. • Type with double-spacing. • See http://jtcs.ctsnetjournals.org/ misc/ifora.shtml for detailed submission instructions. • Submit the letter electronically via jtcvs.editorialmanager.com. Letters commenting on an article published in the JTCVS will be considered if they are received within 6 weeks of the time the article was published. Authors of the article being commented on will be given an opportunity of offer a timely response ( 2 weeks) to the letter. Authors of letters will be notified that the letter has been received. Unpublished letters cannot be returned.
}

also has been shown that rigid rings impose mechanical forces on the mitral annulus that are discordant with its anatomy and dynamic motion. ${ }^{4}$ The current report by Pierce and colleagues provides additional verification of this latter observation. Experimental studies are conducted ostensibly to increase our understanding of physiology, and ultimately, to improve clinical practice. The use of rigid annuloplasty rings secured with interrupted sutures remains entrenched in current cardiac surgical technique. Why is this, given the increasing evidence of detrimental physiological effects and relatively high risk of dehiscence?

Lawrie and colleagues ${ }^{5}$ have reported in the Journal an extensive experience with mitral valve repair using flexible annuloplasty rings secured with a running polypropylene suture. They have observed no instances of ring dehiscence in more than 1000 consecutive patients. Dr John A. Spratt has had a similar experience in a personal series of nearly 300 patients. More consideration should be given to the use this technique, given the greater fidelity of attachment, capacity for normal annular motion throughout the cardiac cycle, and an improved ability to distribute annular tension.

$$
\begin{array}{r}
\text { John R. Spratt, MD, MA } \\
\text { John A. Spratt, MD } \\
\text { Gerald M. Lawrie, MD } \\
\text { a Department of Surgery } \\
\text { Minneapolis, Minn } \\
\text { University of Minnesota Medical School } \\
\text { Minterston } \\
{ }^{b} \text { Cardiothoracic Surgery of Charleston } \\
\text { Roper Hospital } \\
\text { Charleston, SC } \\
{ }^{c} \text { Department of Cardiovascular Surgery } \\
\text { Houston Methodist Hospital } \\
\text { Houston, Tex }
\end{array}
$$

\section{References}

1. Pierce EL, Gentile J, Siefert AW, Gorman RC, Gorman JH III, Yoganathan AP. Real-time recording of annuloplasty suture dehiscence reveals a potential mechanism for dehiscence cascade. J Thorac Cardiovasc Surg. 2016;152:e15-7.

2. Spratt JR, Spratt JA, Beachley V, Kang Q. Strength comparison of mitral annuloplasty ring and suturing combinations: an in-vitro study. J Heart Valve Dis. 2012; 21:286-92.

3. Gorman JH, Gupta KB, Streicher JT, Gorman RC, Jackson BM, Ratcliffe MB Dynamic three-dimensional imaging of the mitral valve and left ventricle by rapid sonomicrometry array localization. J Thorac Cardiovasc Surg. 1996;112: 712-24.

4. Jensen MO, Jensen H, Nielsen SL, Smerup M, Johansen P, Yoganathan AP, et al What forces act on a flat rigid mitral annuloplasty ring? J Heart Valve Dis. 2008; 17:267-75.

5. Lawrie GM, Earle EA, Earle N. Intermediate-term results of a nonresectional dynamic repair technique in 662 patients with mitral valve prolapse and mitral regurgitation. J Thorac Cardiovasc Surg. 2011;141:368-76.

http://dx.doi.org/10.1016/j.jtcvs.2016.07.047 